\title{
FRESH AND SALT: table of contents
}

\begin{tabular}{|c|c|c|c|}
\hline & Heather Goodall & FRESH AND SALT: Introduction & $\mathrm{i}$ \\
\hline \multicolumn{4}{|c|}{ I Meanings for Water } \\
\hline 1 & Jeff Malpas & THE FORMS OF WATER: in the land and in the soul & 1 \\
\hline 2 & Veronica Strang & $\begin{array}{l}\text { TURNING WATER INTO WINE, BEEF AND } \\
\text { VEGETABLES: Material Transformations along } \\
\text { the Brisbane River }\end{array}$ & 9 \\
\hline 3 & Trish FitzSimons & $\begin{array}{l}\text { PEATS RIDGE: a sandy track, citrus farms, } \\
\text { springs, valleys, dams and the politics of ground } \\
\text { water }\end{array}$ & 20 \\
\hline
\end{tabular}

\section{Fresh and Salt in the Pacific}

\begin{tabular}{llll}
\hline 4 & Paul D'Arcy & $\begin{array}{l}\text { SIGNIFICANT SPACES: The Role of Marine } \\
\text { Ecosystems in Pacific Island Cultures }\end{array}$ & 34 \\
& & $\begin{array}{l}\text { Freshwater Lens, Settlement Patterns, Resource } \\
\text { Dirk HR }\end{array}$ & 44 \\
& Spennemann & Use and Connectivity in the Marshall Islands &
\end{tabular}

\section{Water as a Commons}

\begin{tabular}{lllr}
\hline 6 & Janice Gray & $\begin{array}{l}\text { Legal approaches to the ownership, } \\
\text { management and regulation of water from } \\
\text { riparian rights to commodification }\end{array}$ & 64 \\
7 & Tony McAvoy & WATER - Fluid Perceptions & 97 \\
8 & Philip Hirsch & $\begin{array}{l}\text { GOVERNING WATER AS A COMMON GOOD IN THE } \\
\text { MEKONG RIVER BASIN: issues of scale }\end{array}$ & 104
\end{tabular}

\section{Water and Borders}

\begin{tabular}{|c|c|c|c|}
\hline 9 & $\begin{array}{l}\text { Michael Webber, } \\
\text { Jon Barnett, Brian } \\
\text { Finlayson \& Mark } \\
\text { Wang }\end{array}$ & $\begin{array}{l}\text { MANAGING THE YELLOW RIVER: Questions of } \\
\text { Borders, Boundaries and Access }\end{array}$ & 114 \\
\hline 10 & Douglas Hill & THE POLITICS OF WATER IN SOUTH ASIA & 135 \\
\hline \multicolumn{4}{|c|}{ V Reflections [Un-refereed paper] } \\
\hline 11 & Biama Kanasa & $\begin{array}{l}\text { BORDERS ACROSS RIVERS: Problems with the } \\
\text { Creation of Anglo-German Border across Gira, } \\
\text { Eia, Wuwu, and Waria Rivers, 1884-1909 }\end{array}$ & 159 \\
\hline
\end{tabular}

